\title{
Analyzing Complicity in Risk
}

\author{
Jerry Busby*
}

\begin{abstract}
When risks generate anger rather than fear, there is at least someone who regards the imposition of those risks as wrongdoing; and it then makes sense to speak of the involvement in producing those risks as complicity. It is particularly relevant to examine the complicity of risk bearers, because this is likely to have a strong influence on how far other actors should go in providing them with protection. This article makes a case for analyzing complicity explicitly, in parallel with normal processes of risk assessment, and proposes a framework for this analysis. It shows how it can be applied in a case study of maritime transportation, and examines the practical and theoretical difficulties of this kind of analysis. The conclusion is that the analysis has to be formative rather than summative, but that it could provide a useful way of exposing differences in the assumptions of different actors about agency and responsibility.
\end{abstract}

KEY WORDS: Agency; benefit; causation; complicity; voluntarism

\section{INTRODUCTION}

One of the many issues ignored in conventional risk assessment is that of complicity: the involvement that various groups have in the generation of a risk, not as primary agents, nor as the notional risk managers, but as people whose action in some way contributes to the risk. This idea of complicity should be a central concern in risk analysis if we regard this analysis as a route to fairness and reasonableness in ascribing responsibility, accepting or rejecting risks, in working out how much to spend mitigating them, and in prioritizing them for attention.

Having an understanding of complicity looks especially necessary when, as Douglas (1986) argues, risks generate anger rather than fear. Once the relevant emotion is anger, the imposition of the risk-or the failure to reduce it-is seen not merely as being harmful but also wrongful. The risk becomes a reason for anxiety and for blame or censure. When this is the case, being involved in the production of that risk can be called "complicity," not just involvement. And

\footnotetext{
* Address correspondence to Jerry Busby, Department of Management Science, Lancaster University, Bailrigg, Lancaster, LA1 4YX UK, tel: +44 1524 594447; j.s.busby@lancaster.ac.uk.
}

the question of who has the complicity becomes central to who should take responsibility and who should protect risk bearers. It also plays a role in determining whether the anger is taken seriously. Where the risk bearers are themselves complicit, the rest of the world is going to find any anger less defensible, however understandable.

In practice, complicity occurs rarely if ever as an explicit object of analysis in risk assessment. We might assess the probability of trespassing on a railway and the probability of fatality in the event of trespassing, and use the result to decide how much to spend on keeping trespassers out. But we do not assess how complicit they are in the risks they bear, and how much less complicit are child trespassers than adults, and what effect this complicity should have on our spending decisions. Perhaps we exclude such ideas to preserve a notion that risk assessment is value-free and difficult problems of responsibility belong elsewhere. But we have come to realize that even conventional risk assessment is not value-free, and not independent of assumptions about deservingness.

The purpose of this study was to find a way of analyzing complicity, in particular cases, in support 
of risk assessment. This was to be seen not as a way of reaching a definitive, consensual measure, but as a way of reasoning about the link between involvement in a risk and the responsibility to deal with it. We are used to the idea of requiring risk creators and "owners" to use risk assessment processes to reflect on how they produce risk. It seems reasonable by extension to say that other groups who are complicit in a risk, including risk bearers, should reflect on their contributions.

\section{BACKGROUND}

\subsection{References to Complicity}

The idea of complicity gets only occasional attention in the risk literature. Commentary on the risk society includes the idea that complicity arises from our increasing interdependence and increasingly diffuse nature of responsibility (Beck, 1992). There is a kind of complicity when a communitywith a shared knowledge of its industrial historyproduces a compliant and consensual response to the discovery of serious toxic contamination ( $\mathrm{Za}$ vestoski et al., 2002). And complicity gets a mention in cases where it looks like collusion of different groups against the wider public. De Marchi and Ravetz's (1999) analysis of cases of "postnormal science" includes the development of genetically modified crops, and they talk of "the apparent arrogance of the multinationals and the complicity of governments." We therefore get a sense of complicity as something to be found in many layers of organization: as a state of society in general, as a state of a more local community, or as a state of specific groups.

The "complicity" label arises more naturally in connection with consumption rather than production risks. Kline (2004) in particular uses it to describe the behavior of consumers who take risks with their well-being in their choice of lifestyle. Kline's study is of the moral panic surrounding unhealthy foodstuffs, and he analyzes how the issue has involved children, whose ambiguous status is of only partially competent consumers. Adult consumers can broadly be assumed to be sufficiently competent to reason about risk and give an informed consent, but this is clearly more problematic for children. The general case of consumption risks therefore points to high levels of complicity on the part of risk bearers, to the point where they might even be regarded as principals rather than mere accomplices in the risks they bear. But this is always going to need qualifying according to what kind of people they are.

\subsection{Links with Voluntarism}

Early thinking about the perception of risk in terms of voluntariness (Starr, 1969) can also be connected with complicity, in the sense that volunteering for exposure to a risk could be said to make someone complicit in it. There has been a substantial critique of voluntarism. For example, the apparent effects of voluntarism on risk acceptability can readily be explained away by alternative constructs (Slovic et al., 1980), the distinction between the voluntary and involuntary incurring of danger is not objectively identifiable (Douglas \& Wildavsky, 1982), voluntariness can be just as much a matter of perception as risk itself (Jasanoff, 1998), and there are problems with definition and circumstances (Cross, 1998). Activities that appear to be voluntary, for example, driving automobiles, may not feel voluntary to people who believe it is forced on them by circumstances or selected for them by culture. Nonetheless, voluntarism has a useful heuristic value in prioritizing risks for our attention. It is easier to justify spending resources on risks that seem involuntary to the risk bearers.

Complicity is not synonymous with voluntarism. Someone is complicit in the risk they bear of being shot in their own home if they own a firearm, for example, without volunteering to bear the risk of being shot. But it shares with voluntarism an idea of how an involvement in the origin of a risk changes someone's obligations and entitlements. Justifying the protection of people from themselves has always been harder than justifying their protection from external forces, and ideas such as the welfare state have considerably lost their appeal-even in the eyes of their natural supporters (Simon, 2003). Some commentators suggest an increasing inclination of the state to criminalize risk to the self, for example, via seatbelt laws (Adams, 2003). But this still looks like the exception, and perhaps arises from the experience that risks to the self also impose costs on others. So in a general sense both volunteering for a risk and being complicit in it have a parallel role in influencing our priorities for risk management activity.

\subsection{Attitudes of Complicity}

The literature gives us no sense, however, that people feel particularly complicit in the risks they bear. If anything it indicates the opposite. The idea 
that natural dangers have been transformed into decision-based risks (Luhmann, 1993), attitudes that harm is no longer inevitable (Sjöberg, 1987), and the mentality that there should always be someone to blame (Penning-Rowsell, 1996) all suggest a tendency to distance ourselves from the origins of risk. There is a whole range of readily available discourses that we use to attribute collective risks to "the Other" (Bickerstaff \& Walker, 1992). We seem to have traveled from the idea of attributing harmfulness to fate to an idea of attributing it to risk managers without considering the possibility of attributing it to ourselves. And-because what we do is blame and become angry - we also think risks are not just worrying but wrongful. There are exceptions: Douglas and Wildavsky (1982) argue that we hear less of skin cancer contracted from sunbathing because it is not a risk that can be mobilized to criticize an industrysomething that could be construed as people recognizing their own complicity. But generally the replacement of fatalism with agency has produced a burden for risk managers rather than the population at large. This seems bound to produce risk managers whose central concern is risk to their own reputations (Power, 2004). And it seems bound to produce a public increasingly disenchanted with risk management actions.

What we seem to lack is an understanding that the social order that confers protections of various kinds is the same order that produces risks, and that it is often unreasonable to elect for one but not the other. Beck (1992) refers to our "complicity" in the risks of modernism, and the notion that these risks are the byproducts of the choices we have made or at least gone along with. But Beck's view does not look like that of the typical citizen, and Leiss and Chociolko (1994) essentially argue that both individuals and organizations will do little more than try to take the benefits associated with some activity and offload the risks onto others. They are not going to be able to do the offloading unless they show some conviction that they are somehow entitled to do it. Moreover, it may be difficult to understand complicity in a complex society in which there is extensive division of labor, "structural secrecy" (Vaughan, 1996), and atomization, alongside complicated systems of production and governance. This all makes it hard for individuals to identify the links between risk bearing and taking benefits unless they particularly look for them. When they do see such links they may well see them in isolation, not as a normal aspect of living.
Of course, this does not mean that the people lack a capacity to see complicity in others, particularly when the others are corporate actors. A recent example of public judgments of complicity can be found in an outbreak of avian influenza in a processed poultry facility in the United Kingdom, in early 2007. The company in question was judged to be culpable of certain lapses of biosecurity that might have contributed to the outbreak (e.g., Poulter, 2007). Many of the live birds in the facility were culled, and the company received compensation for the culled (but not diseased) birds. There was public outrage that a company that was clearly complicit in the risk of outbreak could later receive compensation in this way (e.g., McGurran, 2007).

\subsection{Emphasizing the Agency of Principals}

Risk studies similarly seem to have emphasized the agency of risk-creating corporations, not the complicity of individual risk bearers. Freudenberg's (1993) work on organizational recreancy concerns conduct unbecoming the level of trust that an organization enjoys. But it raises the question whether those who trust organizations do so appropriately, and whether what we label "trust" is merely a convenient and undiscriminating kind of relying that relieves us of the need to cope with risks ourselves. In Lash and Wynne's (1992) introduction to the translation of Beck's Risk Society there is a view that "the primary risk ... is therefore that of social dependency upon institutions and actors who may well be ... alien, obscure and inaccessible to most people affected by the risks in question." It sounds as though lay people are victims of the institutions on whom they have been rendered dependent. An alternative perspective is that lay people choose to be so dependent because they benefit, choose to go along with institutions that allow them to set aside pressing issues of security, and prefer not to be bothered with the difficult problems of making technology safe.

On a similar theme, Cranor (2007) makes a strong case for regulating chemical risks in a way that sustains individuals' sovereignty over their bodies. Harm-based regulation lets commercial interests effectively experiment with their products on consumers and the public. But this appears to stress the way untested products can "remain in commerce providing benefits for companies" and gives an imbalanced picture where it does not also describe the parallel benefits for consumers. Gillroy's (1992) discussion of the unconditional right of citizens to 
their own agency makes broadly the same argument as Cranor's. Again it raises the question, however, whether this simply lets individuals off the hook of reflecting on how they gain from these apparent losses, and how their taking of the gains sustains the activity that produces the losses. An example is that of brominated flame retardants (e.g., Alcock \& Busby, 2006). These compounds help us manage risks of fire, and in part we use them because a successful campaign to do something about fire risks led to stringent performance standards for goods like furniture. But they have been found in widely distributed environmental compartments and are suspected of toxicity, which has led to campaigns to ban their use. To the extent that these campaigns fail to acknowledge the benefits of their use, they give no sense of what and how we gained in the first place. Gow and Leahy (2005) explain the public's attribution of responsibility for environmental risks to "big business" on the basis of apathy, withdrawal, and disenchantment with the political process. But it also seems likely that people are rarely confronted with an analysis of their own complicity.

\section{ANALYSIS}

\subsection{Complicity and General Usage}

The general meaning of complicity found in dictionaries refers to the states of being an accomplice, being involved, being associated, or participating, all with reference to an act that is criminal, wrong, or questionable. The term therefore addresses a wide spectrum of being, ranging from strong forms like being an accomplice to a crime to weak forms like being merely associated with a questionable act. Sometimes, but not always, complicity is defined as choosing to be involved, indicating that we do not always limit complicity to situations where people have a choice.

It is also instructive to see the term in recent use. Table I is an illustrative rather than definitive summary of how complicity has been used in newspaper articles. The sample consisted of articles in the U.K. press, over the previous 100 days at the time of writing, referring jointly to complicity and risk in any context.

Again this illustrates the relatively wide-ranging usage. Some of the activities in which people are said to be complicit involve extreme acts of evil and criminality, whereas some (such as waste and indus-
Table I. Recent Journalistic Uses of "Complicit" or "Complicity" in the Same Context as "Risk"

trial overproduction) are considerably milder. The nature of the complicity similarly ranges from fairly distant kinds of association to being virtually a principal agent. In some cases the behavior is active, but in other cases passive. Complicity has been ascribed, for instance, to people who fail to act against a questionable activity, take benefits from it, or simply ignore evidence of it. Indeed, Kissell (1999) argues that it is rooted in Western language and narratives that complicity extends to the idea of merely tolerating wrongdoing. This goes well beyond the criminality of being complicit, which specifically concerns causation: that is, "whether we can meaningfully say that one person can 'cause' another person to engage in volitional action" (Weisberg, 2000). Being a cause is normally limited to the two aspects of inciting or aiding a crime (e.g., Dubber, 2007). Criminal complicity appears also to differ from more general usage in referring to the state of being a partner in crime without specifically being a lesser or minor partner (Eboe-Osuji, 2005). 
The idea of being complicit in a risk, especially when it is meant to support a general process of risk management rather than criminalizing individuals, needs to reflect this breadth of general usage. If it is to be informative rather than judgmental, it should be inclusive, not exclusive: the milder kinds of complicity are potentially as interesting as the stronger kinds, not least because they are likely to apply to many more people. In the remainder of this section an attempt is therefore made to identify the multiple bases for ascribing complicity, including those that might be seen as only weak bases-insufficient for condemning or criticizing someone, but nonetheless relevant to questions of how best to manage risk.

\subsection{Complicity and Causation}

Having a causal role in some risk is not the only basis for saying that someone is complicit in it, but it is the most obvious basis. A large causal contribution - one without which the risk cannot exist, for instance-intuitively implies more complicity.

This causal contribution is moderated by knowledge. An example of how knowledge contributes to complicity can be found in Weisberg's (2000) discussion of the individual who sold guns to the murderers in the Columbine High School case. He had "at worst exhibited recklessness, not knowledge, with respect to the killers' actions," and in the end was convicted only of "violating a very limited Colorado statute forbidding certain gun sales to minors." But his involvement with the murderers was complex, having met them at a gun show some months earlier, procured them a handgun, and supplied them with ammunition. Even though he was not charged with complicity in the murder, it is very hard to argue that morally he completely lacked complicity. The case thus speaks to our feelings that-while specific knowledge is important to judgments of complicity-a lack of knowledge does not entirely avoid it. If nothing else it is not hard to imagine a gun being used to kill people, and knowledge even of this imaginative kind can make someone complicit.

Causation as a basis for complicity is also moderated by agency. Questions of agency have been seen generally as an important aspect of risk management (Caplan, 2000), and the more agency someone enjoys in making their causal contribution the more complicit they are. But it also depends on what the agency is directed at. The analysis of intentionality (Searle, 1983; Bratman, 1987) indicates that you can know some outcome is the by-product of what you are endeavoring to do without that outcome being your intention. Bratman (1987) describes the example of a "strategic" bomber and a "terror" bomber. Both end up knowingly bombing schools-the first because (s)he has the intention of a bombing a factory that happens to be located next to a school, the second because (s)he has the intention of bombing the school in order to terrorize the population. In the first case, the bombing of the school looks reckless but is not the intention; in the second case it is the intention. We could argue that (1) the greatest complicity arises when someone has the intention of contributing to a risk; (2) less complicity arises when they know their action will contribute to a risk without that being their intention; and (3) even less complicity arises when their contribution is not the result of acting intentionally at all. An example of the last case is when someone's unavoidable physical condition puts them specifically at risk in a particular situation-for example, people who cannot swim on board a boat that has capsized at sea. Examples of the second case include situations in which actors enjoy agency but believe they are caught in a "systemic net of circumstances" (Horlick-Jones, 1996).

\subsection{Complicity and Choosing}

A connection between complicity and voluntarism was suggested earlier. Although there are difficulties with voluntarism as a construct, it still seems reasonable to say that when someone has a choice, and chooses a risky activity, they are complicit in the risks they bear. It looks like a weaker form of complicity than causal involvement because it suggests someone choosing to expose themselves to a risk whose form is determined by other agents. It is also affected by the directness of the risk that follows the choice. For example, someone might choose to work in a location that forces them to use a ferry to get to work. They appear less complicit in the risks of traveling by ferry than someone who has the option of a ferry and a journey by automobile, and chooses the ferry explicitly.

An example of complicity arising from a voluntary exposure is that of workers using vibrating machinery in highway construction and maintenance firms. There are fairly rigid standards limiting the time for which certain kinds of machinery are used by individuals, to minimize the risk of contracting conditions like "vibration white finger." Workers occasionally exceed these limits, generally to complete a task that would otherwise be interrupted. Their 
employers also, inadvertently, create the conditions in which it is often easier to exceed the limits than obey them. Nonetheless, it is still a choice when workers do exceed these limits, and so they ought to be seen as complicit in the resulting risk.

Again the idea that choice means complicity is moderated by knowledge. Being knowledgeable about the risks entailed in a choice implies a greater degree of complicity, as does failing to take reasonable steps to know about a risk - that is, being "willfully ignorant." Unfortunately, it is not always easy to characterize knowledge in the context of risk because what we can and do know are often contested. Another apparent example of complicity through choice, with knowledge, is the use of cellphones following the publicizing of radiation risks (Burgess, 2004). There is a whole range of issues around the scientific and public understanding of these risks that makes it very hard to simply characterize someone as knowledgeable or ignorant, and if ignorant, as willfully or inadvertently ignorant. It is therefore hard to be specific about the extent of their complicity.

\subsection{Complicity and Consent}

Another reason for speaking of someone as being complicit in a risk, as a risk bearer, is that they consent to it in some way. This is obviously the case if the risk has been correctly and comprehensively described, and the consent is given directly. Where consent is indirect (MacLean, 1982), or where it is direct but lacking in the normal requirements-for example, being uninformed or coerced-complicity is going to be substantially lower.

A further caveat is that, as Rayner (1987) points out, cultural analysis reveals that different types of organization favor different means of obtaining consent. Individualist organizations favor revealed preferences, bureaucratic organizations favor hypothetical consent, and egalitarian groups favor explicit, ranked values. It is not necessarily the case that those whose consent is sought go along with the method chosen by those seeking the consent. So, although there is an obvious general link between consent and complicity, the particular nature of the consent, and the context, need to be taken into account. It seems reasonable to say that (1) someone is more complicit if they consent directly than if someone consents for them (a politician in a representative democracy, for instance); (2) someone is more complicit if they consent specifically rather than generally, or consent to a particular case rather than a general rule; and that (3) someone is more complicit if the consent is active rather than passive or by default. But the consent-complicity relationship cannot be divorced from the cultural context and reasoning about complicity needs to be responsive to this context.

\subsection{Complicity and Benefit}

The early work on risk perception pointed to the relationship between risk and benefit (Starr, 1969). There is a case for considering those who benefit from an activity as being complicit in risks arising from it. It looks like a very weak form of complicity if the risk is unknown to the beneficiary, but could be much stronger where a group knows that taking benefits sustains an activity and knows that it produces risk. And even when beneficiaries lack this specific knowledge, it would be naïve of anyone to assume that they can gain access to a benefit without some kind of risk: the risk-benefit relationship seems to be a fundamental aspect of life (Leiss \& Chocioloko, 1994).

This does not mean that someone who is a beneficiary necessarily feels as though they are complicit. Studies of risk perception have found that, whereas risk and benefit tend to be positively correlated in the world, they can be negatively correlated in people's judgments (Slovic et al., 2004). We do not seem to assume that an activity we derive much benefit from entails a lot of risk. And, although one or two of the entries in Table I referred to complicity as taking benefits, this is not a universal view. For example, Robertson (1999) argues that using tissue from aborted fetuses can be without "moral complicity" in the underlying abortion, even though obtaining stem cells from embryos necessarily kills those embryos.

We therefore need to see the attribution of complicity to someone because they are a beneficiary as being potentially controversial. But if the purpose of the analysis is not to allocate blame or seek redress, then there is less at stake in attributing complicity to beneficiaries, and it has become a commonplace principle that benefits justify risks, and vice versa.

\subsection{Complicity and Participation}

A final basis for complicity is participating in the group or society that produces a risk-even when the other criteria, like taking a benefit, giving consent, and making a choice, do not apply. There is a sense in which someone's participation in some order in which a risk arises makes them involved, and 
potentially makes a difference to how deserving they are of protection from that risk.

Again, someone's knowledge is relevant to our ideas about their complicity, and again it matters whether the ignorance is "willful." Willful ignorance looks worse than inadvertent ignorance, although possibly not as bad as specific knowledge. An interesting, if outlying case, of willful ignorance can be found in Luban's (1999) discussion of Albert Speer and his guilt in the crimes of Nazism, particularly the extermination camps. He describes how Speer denied knowing anything about the Final Solution, but also how he acknowledged that he chose not to know. Yet he also seemed clear that willful ignorance was "just as bad as knowledge" and therefore accepted full responsibility for the Third Reich's crimes. Luban argues that Speer was treated more leniently because he "understood that the best way to dodge responsibility is to assume it - but not to assume responsibility for any particular heinous deeds." There is also a sense that Speer gets credit for being contrite, and his contrition looks greater when he freely says that his willful ignorance was as bad as knowledge. Thus, specific knowledge of a crime or harm makes someone especially complicit; ignorance subtracts from this complicity; willful ignorance subtracts from this subtraction; but, possibly, contrition subtracts from this subtraction in turn.

It could be argued that if there is no suspicion of harm or wrongdoing, there could not be willful ignorance, and that inadvertent ignorance would get someone off the hook of any kind of complicity. But it is possible to think of cases where this is not true. Perhaps the most obvious example is indeed that of high-ranking people in organizations. Higher rank means a greater embodiment of institutional behavior in the individual manager (Iedema, 1998). Senior people are complicit in the workings of an organization and any risk it produces, even if they played no role in producing the risk and had no suspicion of it. Perhaps we just want to hold senior officers morally responsible for risks in their organizations; perhaps we think they are implicated causally—-through exercising insufficient oversight. It may be, though, that they are simply an important part of a system that wrongfully imposes risks, and that that is enough to call them complicit.

There is a similar situation with people involved in the production of some risk where the risk is a cumulative consequence of many people acting in the same way, none of whom intend the accumulated outcome. In his essay on the so-called law of unintended consequences, Vernon (1979) traces a line from individuals dropping litter on hitherto unspoiled mountains, through material acquisitiveness that cumulatively produces ecological damage, to individuals acquiescing to authority that, when accumulated, produces acts of tyranny. As we reach the last of these cases, Vernon argues that we find the individuals' participation blameworthyeven if it was not clear to them what the outcome would be and even though, individually, they could not have prevented it by withdrawing their participation.

Participation of this kind is the basis of Kutz's (2000) analysis, which is that actors are responsible for the things they participate in, "regardless of whether the participation makes a causal difference to the outcome" (May, 2002). May's (2002) review of Kutz's book points to another wartime case-the bombing of Dresden, and the idea that many people beyond the pilots of the aircraft that dropped the bombs, and even beyond those who gave the orders, bore responsibility. Where there is no aspect of benefit, choice, or consent, let alone causation, the complicity looks weak. Kutz's notion of participation is participation in a wrongful act, not merely participation in the organization that produces a wrongful act. Nonetheless, it seems important to preserve some residue of complicity for someone who is part of a social order that produces or sanctions a risk.

\subsection{A Normative Framework}

These five bases for complicity provide a simple framework for guiding a complicity analysis. As has been indicated, the context matters to this analysis, and there are several factors moderating each of the main bases. But if the purpose of the analysis is to encourage reflection - that is, to be formative-rather than to reach a summative measure of some kind, it seems better to aim for simplicity. Table II collects these bases together and shows them in roughly descending order of degree. It also shows what each basis adds to the next (when working upward) and what each subtracts from the next (when working downward).

Any analysis that uses these basic cues is unlikely to be consensual, so the purpose should not be to seek consensus. Different groups should be able to perform their own analyses, and discrepancies among different analyses should be treated as interesting rather than problematic. Moreover, the analysis 
Table II. A Basic Framework to Prompt the Analysis of Complicity

\begin{tabular}{lll}
\hline Basis & What is Removed in Moving Down to This Level & What is Added in Moving Up to This Level \\
\hline $\begin{array}{ll}\text { Causation } \\
\text { Choice }\end{array}$ & Not bringing about or shaping the risk & Being able to produce or shape the risk \\
Consent & Not having an alternative but to be involved in the risk & Being able to choose among alternatives \\
Benefit & Not having the opportunity to agree or allow the risk & Being able to agree to the risk \\
Participation & Not gaining from the risk & \\
\hline
\end{tabular}

should provide a background to decision making rather than play a predetermined role in it. Judgments of complicity are so obviously political as well as analytical that the idea of complicity would lose credibility, rather than gain it, from being a part of a mechanistic process. These points seem to preclude the use of complicity as part of a risk acceptance formula-for example, modifying risk acceptance thresholds for a given group in the light of their complicity. But a formulaic analysis of complicity looks unreasonable in any case.

Another approach is to use the analysis to improve the day-to-day management of risk, rather than formal decision processes. For example:

1. Where certain groups are complicit they may be co-opted more effectively to deal with risk. A complicity analysis should help reveal the origin of many risks in joint, rather than individual, actions, and emphasize the shared, nonexclusive responsibility that accompanies them.

2. Such groups might be offered options that are specifically adapted to their complicity. For example, they might be offered insurance or other "risk products" (Burgess, 2004, p. 21) in which they pay a price, if a small one, for risk reductions rather than placing the burden on risk managers.

3. Ultimately, it may be that the aim becomes to cope with, rather than mitigate, a risk. Coping might mean controlling a risk in some way, but it might equally amount to reconciling ourselves to it, attributing it to some agency that makes it tolerable, forgetting about it, reframing or reconceptualizing it. Douglas's (1986) observation on risks producing anger rather than fear leads to the thought that certain groups may cope better with a risk when they recognize their own complicity. It is important not to be glib about such possibilities, but in some situations they might be suitable.
In the next section, we use a case study to explore the difficulties of applying the basic framework, and discuss what kind of decision process or management process this information might be useful for.

\section{CASE STUDY}

\subsection{Background to the Case}

The case study is based on a risk assessment undertaken for a national maritime regulator of commercial operations on tidal rivers and estuaries (with a mean of 148 passengers on a vessel), inland waterways (a mean of 48 passengers), lakes (105), and coastal waters (76). The case was chosen because there are some obvious ways in which well-defined groups, such as passengers and employees, can contribute to the causation of hazards. There are some fairly obvious ways in which consent is given-as employees, or as passengers booking a passage. And the risks are generally mundane: which is not to discount their scale (the loss of the Marchioness in 1989 in the United Kingdom killed 51 people) but to say that they are not arcane, complex, obscure, or especially technical. They generally have their roots in the kind of organizational dysfunction that most people are familiar with, not in the limits of scientific understanding. This kind of situation also represents a middle ground between risks in which there is no, or virtually no, complicity, and risks in which the complicity is obvious and considerable.

\subsection{An Indicative Analysis}

The purpose of the case study was to find out what kind of judgments would be needed to apply the framework sketched out in the last section, and to get some sense of the problems that accompany these judgments. Our starting point was the original risk assessment, and the complicity analysis broadly followed its structure. The main hazard categories in the risk assessment were collision, grounding, contact, fire or explosion, flooding, and personal accidents. 
Table III. Local Passenger Vessels Study—Hazards and Complicity Types for Passengers

\begin{tabular}{|c|c|c|}
\hline Identified Hazard & Potential Complicity of Risk Bearers & Possible Moderating Factors \\
\hline $\begin{array}{l}\text { Crowd control failure on board, or } \\
\text { during boarding, or disembarking }\end{array}$ & $\begin{array}{l}\text { Causal: crowding behavior, impatience } \\
\text { (moderate), ignoring crew instructions } \\
\text { (high) }\end{array}$ & $\begin{array}{l}\text { Events beyond individuals' influence (high) } \\
\text { Incompetent or provocative crew action } \\
\text { (moderate) }\end{array}$ \\
\hline $\begin{array}{l}\text { Instability, obstruction, or poor condition } \\
\text { of gangway, jetty, or pontoon during } \\
\text { boarding }\end{array}$ & $\begin{array}{l}\text { Causal: queue jumping (moderate), } \\
\text { lacking in agility (moderate) }\end{array}$ & $\begin{array}{l}\text { Design and condition of physical environment } \\
\text { (high) }\end{array}$ \\
\hline Harmful contact with mooring lines & $\begin{array}{l}\text { Causal: inattention (moderate) } \\
\text { Choice: crossing barriers (moderate) }\end{array}$ & $\begin{array}{l}\text { Distracting events (moderate) } \\
\text { Design of physical environment (moderate) }\end{array}$ \\
\hline $\begin{array}{l}\text { Access to vessel on steep angle or by } \\
\text { disabled or intoxicated passengers }\end{array}$ & Causal: disablement, intoxication (high) & $\begin{array}{l}\text { Lack of agency in personal capacities such as } \\
\text { disability (high) }\end{array}$ \\
\hline Harm to limbs projecting outside vessel & Causal: inattention (high) & Design of physical environment (moderate) \\
\hline Collision with berth & Causal: distracting behavior (moderate) & $\begin{array}{l}\text { Conditions arising that demand attention } \\
\text { (moderate) }\end{array}$ \\
\hline $\begin{array}{l}\text { Collision impact with bridges, moorings, } \\
\text { or other vessels }\end{array}$ & As above & As above \\
\hline Collision with swimmers or rowers & $\begin{array}{l}\text { Causal: unpredictable behavior } \\
\text { Choice: swimming in crowded waters }\end{array}$ & $\begin{array}{l}\text { Difficult conditions reducing visibility or control } \\
\text { (moderate) } \\
\text { Incompetent or inappropriate boatmanship } \\
\text { (moderate) }\end{array}$ \\
\hline Fires and explosions on vessel & $\begin{array}{l}\text { Causal: taking flammable materials on } \\
\text { board, using them in hazardous areas } \\
\text { (high) }\end{array}$ & Flammable materials left exposed (moderate) \\
\hline Acts of vandalism or terrorism & $\begin{array}{l}\text { Tolerating: acquiescing to vandalism } \\
\text { (low) }\end{array}$ & \\
\hline $\begin{array}{l}\text { Language barriers in understanding } \\
\text { safety instructions }\end{array}$ & Causal: lacking native language & $\begin{array}{l}\text { Lack of agency in personal capacities (moderate } \\
\text { to low) }\end{array}$ \\
\hline Boat rage & Causal: individual behavior (high) & Crowded waters (low) \\
\hline Panic among passengers in tunnels & $\begin{array}{l}\text { Causal: individual reaction, crowd } \\
\text { behavior (moderate) }\end{array}$ & $\begin{array}{l}\text { Lack of agency in behaviors exhibited in panic } \\
\text { (moderate) }\end{array}$ \\
\hline Harm during evacuation & $\begin{array}{l}\text { Causal: individual capacities such as } \\
\text { being a poor swimmer, intoxication, } \\
\text { being disabled }\end{array}$ & $\begin{array}{l}\text { Lack of agency in certain capacities (high to } \\
\text { low) }\end{array}$ \\
\hline \multirow[t]{3}{*}{ All hazards } & $\begin{array}{l}\text { Benefit: receiving a service, often a } \\
\text { leisure service (low) }\end{array}$ & No alternative to using the service (moderate) \\
\hline & Choice: choosing the operator (low) & $\begin{array}{l}\text { Being a child or otherwise having less capacity } \\
\text { to choose (high) }\end{array}$ \\
\hline & $\begin{array}{l}\text { Consent: going along with the obvious } \\
\text { risks of sailing (moderate) }\end{array}$ & Being unfamiliar with sailing (moderate) \\
\hline
\end{tabular}

Fault tree and event tree analysis were used in an engineering-like assessment process, based on a mixture of expert judgment and historical data. This quantified the annual risk to crew and passengers from 47 hazards, which were not mutually exclusive. Some of these seem to involve little complicity (e.g., low flying aircraft), so were removed from the analysis. In Table III the remaining sample of hazards is listed, together with some possible bases for attributing complicity to passengers as risk bearers. An indication of how complicity might be moderated in particular cases is given in the third column of the table. Although the analysis concentrates on passengers as risk bearers, it could equally well be replicated for crews.
An attempt is also made in the table to give a very approximate idea of the degrees of complicity involved, in both the main bases for judging complicity and the moderating factors.

\subsection{Observations on the Analysis}

Table III suggests that most complicity in this case arises from causal involvement. Risk bearers are complicit in, for example, crowd control failures because their behaviors or dispositions are necessary to the harm in question. This emphasis on causal involvement is partly an artifact of following the structure of the original risk assessment, which is largely organized around a causal analysis. The other bases 
for complicity, like giving consent and receiving benefit, are less clearly linked to particular hazards, and so are grouped together at the bottom of the table under a nonspecific, "all hazards" heading.

Assigning degrees of complicity to the entries in Table III was problematic because even in the context of a specific hazard, there was a wide range of potential behaviors. For example, crowd control failure can arise from antisocial, unreasonable, or inappropriate behavior on the part of passengers, or from confusing, aggressive, or incompetent action on the part of staff. The risk bearers are also a heterogeneous group-some being children, some drunk, some disabled, and so on.

Another observation is that there is no distinction between two kinds of complicity judgment that have different meanings. Someone buying a ticket, who chooses to benefit from an activity with obvious risks, goes along with those risks and could be said to be weakly complicit in them. But if we look at a passenger in the present, and suggest it is possible they could behave in a way that creates a risk in the future (e.g., through drunkenness), we are only saying they would be complicit if that is how they behaved. It is more a risk of complicity than complicity in a risk. It is therefore important to remember that the purpose of the analysis is not to censure people, but instead to assist in the process of managing risk. A risk manager can say to someone who is complicit in a risk "we will spend less on mitigating that risk because of your complicity," and can equally say to someone who is at risk of being complicit "we will spend less on mitigating that risk because, if it arises, you will be complicit in it."

There is a similar problem with failing to distinguish wrongdoing and harm. Some of the judgments in Table III point to wrongdoing because they are about behaviors that put others, as well as the agent in question, at risk. Individual acts on boats can produce collective disasters. It is also a commonplace idea that drunken or irresponsible people who risk their own necks also risk the necks of those who try to rescue them. Some of the entries also point to wrongdoing where it can be construed that the corporation in question exercised insufficient care. But there are some entries in Table III that would be hard to read as wrongdoing, and in such cases the idea of complicity looks overextended.

A fourth observation is that some of the judgments in Table III are simply debatable. For example, there are uncertainties about the extent of actors' agency when they panic, or behave as part of a crowd. There are uncertainties about knowledge: failure modes involving "overcrowding" raise the question as to how much those involved in the crowd can know what amounts to overcrowding, what occurs as a result, and how much they can rely on the crew to manage overcrowding. And there are problems with choice. For instance, are disabled people more complicit when choosing to place themselves at higher risk, by choosing to sail? Or should we work from the assumption that any individual choosing to consume the same service as someone else can expect the provider to ensure they bear the same risk?

\section{CONCLUSION}

Analyzing complicity in a risk is essentially about how high a horse you can get upon when demanding protection from that risk. The more complicity a risk bearer can be regarded as having, the more risk managers can question the allocation of resources to protecting them. It does not have to follow that resources are denied when people are complicit, but the need for protection is then less axiomatic. This complicity arises in a number of ways, ranging from causal involvement, through choice, consent, and taking benefits, to merely participating in a group or activity in which the risk arises. How much the people in question know, how willful is their ignorance, and how much agency they can exercise all modify our view of their complicity.

There are various problems in this analysis, notably the indeterminacy of some of the judgments that need making. But even the limited complicity analysis given here provides a systematic way of reasoning about the role of risk bearers, and other groups more widely, in the generation and management of risks that are seen questionable or wrongful in some way. It offers a way of looking at the different perspectives of different groups, it might contribute to a more authentic kind of risk communication (Otway \& Wynne, 1989), and it seems to fit the notion of a "risk characterization" that is much broader than the usual risk assessment (Stern \& Fineberg, 1996).

Variousx lines of further work could be suggested. One would be to examine complicity in the context of quite different risks, particularly those in which the risk is of widespread collective harm such as climate change. A second possibility would be to test expressed preferences. Groups who might be thought complicit in a risk could be asked: "If you accept complicity what price would you pay to have this removed in all considerations of management or 
compensation?" And risk managers could be asked: "If you attribute complicity to some group what contribution would you expect to receive from it toward the costs of making the risk acceptable?" Another line of work would be to incorporate a complicity analysis explicitly in a public consultation, as a way of testing its usefulness in revealing what distinguishes the perspectives of different stakeholders. Finally, it would be illuminating to survey how people in various groups reason about complicity, when they think it arises and what they think it entails.

\section{ACKNOWLEDGMENTS}

Many thanks are due to the anonymous reviewers of an earlier draft of this article.

\section{REFERENCES}

Adams, J. (2003). Risk and morality: Three framing devices. In R. V. Ericson \& A. Doyle (Eds.), Risk and Morality (pp. 87-104). Toronto: University of Toronto Press.

Alcock, R. E., \& Busby, J. S. (2006). Risk migration and scientific advance: The case of flame retardant compounds. Risk Analysis, 26, 369-382.

Beck, U. (1992). Risk Society: Towards a New Modernity. London: Sage.

Bickerstaff, K., \& Walker, G. (2002). Risk, responsibility, and blame: An analysis of vocabularies of motive in airpollution(ing) discourses. Environment and Planning A, 34, 2175-2192.

Bratman, M. E. (1987). Intention, Plans, and Practical Reason. Cambridge, MA: Harvard University Press.

Burgess, A. (2004). Cellular Phones, Public Fears, and a Culture of Precaution. Cambridge, UK: Cambridge University Press.

Caplan, P. (2000). Introduction. In P. Caplan (Ed.), Risk Revisited (pp. 1-28). London: Pluto Press.

Cranor, C. (2007). Fron guinea pigs to sovereigns: A new proposal about the morality of protection from chemical invaders. 2007 Gordon Cain Conference, 22-23 March, Philadelphia, PA.

Cross, F. B. (1998). Facts and values in risk assessment. Reliability Engineering and System Safety, 59, 27-40.

De Marchi, B., \& Ravetz, J. R. (1999). Risk management and governance: A post-normal science approach. Futures, 31, 743757.

Douglas, M. (1986). Risk Acceptability According to the Social Sciences. London: Routledge \& Kegan Paul.

Douglas, M., \& Wildavsky, A. (1982). Risk and Culture: An Essay on the Selection of Technological and Environmental Dangers. Berkeley, CA: University of California

Dubber, M. D. (2007). Criminalizing complicity. A comparative analysis. Journal of International Criminal Justice, 5, 9771001.

Eboe-Osuji, C. (2005). Complicity in genocide "versus" aiding and abetting genocide. Journal of International Criminal Justice, 3 , $56-81$.

Freudenberg, W. R. (1993). Risk and recreancy: Weber, the division of labour, and the rationality of risk perceptions. Social Forces, 71, 909-932.

Gillroy, J. M. (1992). Public policy and environmental risk: Political theory, human agency, and the imprisoned rider. Environmental Ethics, 14, 217-237.
Gow, J., \& Leahy, T. (2005). Apocalypse probably: Agency and environmental risk in the Hunter region. Journal of Sociology, $41,117-141$.

Horlick-Jones, T. (1996). The problem of blame. In C. Hood \& D. K. C. Jones (Eds.), Accident and Design. Contemporary Debates in Risk Management (pp. 61-71). London: UCL Press.

Iedema, R. A. M. (1998). Institutional responsibility and hidden meanings. Discourse and Society, 9, 481-500.

Jasanoff, S. (1998). The political science of risk perception. Reliability Engineering and System Safety, 59, 91-99.

Kissell, J. L. (1999). Complicity in thought and language: Toleration of wrong. Journal of Medical Humanities, 20, 49-60.

Kline, S. (2004). Fast food, sluggish kids: Moral panics and risky lifestyles. Cultures of Consumption Working Paper Series. Available at http://www.bbk.ac.uk. Accessed on 4/24/07.

Kutz, C. (2000). Complicity: Ethics and Law for a Collective Age. Cambridge, UK: Cambridge University Press.

Lash, S., \& Wynne, B. (1992). Introduction. In U. Beck (Ed.), Risk Society: Towards a New Modernity (pp. 1-8). London: Sage.

Leiss, W., \& Chociolko, C. (1994). Risk and Responsibility. Montreal: McGill-Queen's University Press.

Luban, D. (1999). Contrived ignorance. Georgetown Law Journal, $87,957-980$

Luhmann, N. (1993). Risk: A Sociological Theory. Berlin: Walter de Gruyter.

MacLean, D. (1982). Risk and consent: Philosophical issues for centralized decisions. Risk Analysis, 2, 59-67.

May, L. (2002). Review of "Complicity: Ethics and law for a collective age". Philosophical Review, 111, 483-486.

McGurran, A. (2007). £589,356.89 compensation gobbled up by bird flu firm. Mirror, April 20, 23.

Otway, H., \& Wynne, B. (1989). Risk communication: Paradigm and paradox (guest editorial). Risk Analysis, 9, 141-145.

Penning-Rowsell, E. (1996). Criteria for the design of hazard mitigation institutions. In C. Hood \& D. K. C. Jones (Eds.), Accident and Design: Contemporary Debates in Risk Management (pp. 127-140). London: UCL Press.

Poulter, S. (2007). Did complacency let the bird flu in? Daily Mail (London), February 5, 10.

Power, M. (2004). The Risk Management of Everything: Rethinking the Politics of Uncertainty. London: Demos.

Rayner, S. (1987). Risk and relativism in science for policy. In B. B. Johnson \& V. T. Covallo (Eds.), The Social and Cultural Construction of Risk. Essays on Risk Selection and Perception (pp. 5-23). Dordrecht: Reidel.

Robertson, J. A. (1999) Ethics and policy in embryonic stem cell research. Kennedy Institute of Ethics Journal, 9, 109-136.

Searle, J. R. (1983). Intentionality. Cambridge: Cambridge University Press.

Simon, J. (2003). Risking rescue: High altitude rescue as moral risk and moral opportunity. In R. V. Ericson \& A. Doyle (Eds.), Risk and Morality (pp. 375-406). Toronto: University of Toronto Press.

Sjöberg, L. (1987). Foreward. In L. Sjöberg (Ed.), Risk and Society (pp. vii-viii). London: Allen and Unwin.

Slovic, P., Finucane, M. L., Peters, E., \& MacGregor, D. G. (2004). Risk as analysis and risk as feelings: Some thoughts about affect, risk, and rationality. Risk Analysis, 24, 311-322.

Slovic, P., Fischhoff, B., \& Lichtenstein, S. (1980). Facts and fears: Understanding perceived risk. In R. C. Schwing \& W. A. Albers (Eds.), Societal Risk Assessment (pp. 181-216). New York: Plenum Press.

Starr, C. (1969). Social benefit versus technological risk. Science, $165,1232-1238$.

Stern, P. C., \& Fineberg, H. V. (Eds.) (1996). Understanding Risk: Information Decisions in a Democratic Society. Committee on risk characterization. Commission on behavioral and social 
sciences and education. Washington, DC: National Research Council. National Academy Press.

Vaughan, D. (1996). The Challenger Launch Decision (p. 239). Chicago, IL: University of Chicago Press.

Vernon, R. (1979). Unintended consequences. Political Theory, 7, $57-73$.
Weisberg, R. (2000). Reappraising complicity. Buffalo Criminal Law Review, 4, 217-281.

Zavestoski, S., Mignano, F., Agnello, K., Darroch, F., \& Abrams, K. (2002). Toxicity and complicity: Explaining consensual community response to a chronic technological disaster. Sociological Quarterly, 43, 385-406. 